\title{
生化学からみた動脈硬化研究への提言
}

\section{分子生物学からみた高脂血症の成因と動脈硬化 ${ }^{*}$}

馬宏**

近年, 分子生物学, 分子遺伝学の進歩は目覚ま しく, 臨床応用も可能となってきた. 1 つの臨床 所見が生理的に解明され，さらに生化学的機構が 明らかになり，蛋白分子レベルから最終的に遺伝 子レベルで検討されることになる.家族性高コレ ステロール血症 (Familial Hypercholesterolemia, FH）を例にとると Fig. 1 のような研究過程が考 えられる. 最近では臨床事実をいきなり遺伝子レ ベルで検討し, そこから逆に病態生理学的機構が 明らかにされることも多い (reverse genetics)。動 脈硬化の原因の 1 つとして重要な脂質代謝異常に 関係したアポ蛋白, リポ蛋白レセプター, 酵素, 脂質運搬蛋白の遺伝子 DNA はほとんど解明され ており (Table 1), それらの染色体上の局在もほと んど明らかにされている (Fig. 2).

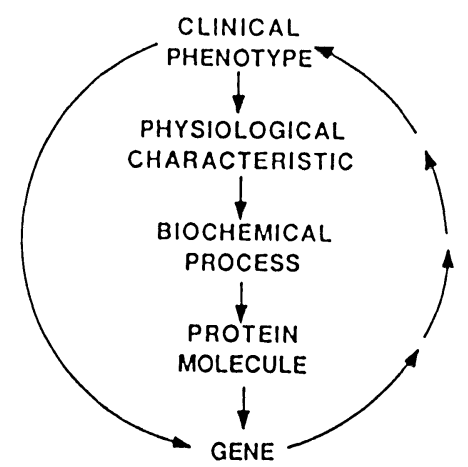

組み換え DNA を用いた研究手技を臨床に応用 すれば以下のことが可能である．1)疾患の成因の 解明：とくに単一疾患と考えられていたものが遺 伝子レベルで多様性が明らかになる。2) 疾患の診 断：とくに出生前扔よび新生児診断が容易となる. 3) 疾患のスクリーニング : 遺伝子レベルで多様 性があると必ずしも容易ではない，4）遺伝子治 療：目下は臨床応用は期待できない。

著者らは FH 患者の LDL レセプター (LDLR) 遺伝子の検討を行った ${ }^{1)}$. 85 家系中 14 家系 (17\%) に遺伝子の異常部位を確認した (Table 2). LDLR のエクソン 15 を中心に $6 \mathrm{~kb}$ 欠損する例 を $\mathrm{FH}_{\text {TONAMI }} 1^{2)}$, エクソン 2,3 を含む $10 \mathrm{~kb}$ 欠損 例を $\mathrm{FH}_{\mathrm{TONAMI}}{ }^{3)}$, エクソンを 2,3 を含む $12 \mathrm{~kb}$ 欠損例を $\mathrm{FH}_{\mathrm{KANA} \mathrm{Z}_{A \mathrm{WA}}} 1$ と命名した. LDLR 遺伝

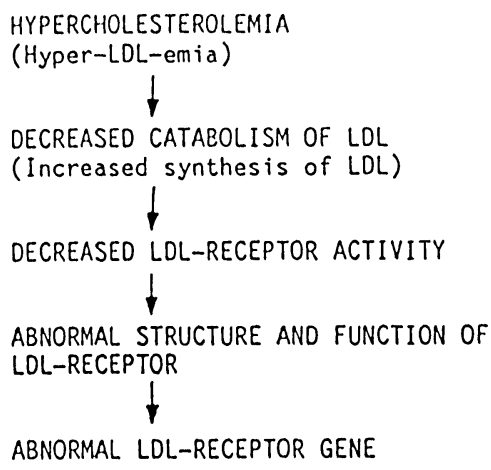

Fig. 1 Strategies for relating phenotypes and genes in familial hypercholesterolemia.

* 1988 年 6 月, 第 20 回日本動脈硬化学会総会におい て発表

** 金沢大学医学部第二内科 
動脈硬化 Vol. 17 No. 31989

Table 1 Human genes associated with lipid metabolism

\begin{tabular}{|c|c|c|c|c|c|}
\hline & \multicolumn{2}{|c|}{ No. of amino acid } & \multirow{2}{*}{ cDNA } & \multirow{2}{*}{ Gene } & \multirow{2}{*}{ Chromosome } \\
\hline & Precursor & Mature & & & \\
\hline \multicolumn{6}{|l|}{ Apolipoproteins } \\
\hline A-I & 267 & 243 & 893 & 1,860 & 11 \\
\hline A-II & 100 & 77 & 437 & 1,750 & 1 \\
\hline A-IV & 396 & 376 & 1,440 & 2,400 & 11 \\
\hline B-100 & 4,563 & 4,563 & 14,100 & 43,000 & 2 \\
\hline B-48 & 2,152 & 2,152 & 6,457 & 43,000 & 2 \\
\hline C-I & 83 & 57 & 440 & 3,200 & 19 \\
\hline C-II & 101 & 79 & 450 & 3,338 & 19 \\
\hline C-III & 99 & 79 & 507 & 3,000 & 11 \\
\hline D & 189 & 169 & 850 & & 3 \\
\hline $\mathrm{E}$ & 317 & 299 & 1,163 & 3,700 & 19 \\
\hline $\operatorname{Lp}(\mathrm{a})$ & 4,548 & 4,529 & 13,644 & & \\
\hline \multicolumn{6}{|l|}{ Receptor } \\
\hline LDL & 860 & 839 & 5,300 & 45,000 & 19 \\
\hline \multicolumn{6}{|l|}{ Enzymes } \\
\hline HMG-CoA reductase & 888 & 888 & 4,300 & & 5 \\
\hline LCAT & 440 & 416 & 1,550 & 4,200 & 16 \\
\hline LPL & 475 & 448 & 1,720 & & 8 \\
\hline Hepatic lipase & 499 & 476 & 1,497 & & 15 \\
\hline \multicolumn{6}{|l|}{ Transfer protein } \\
\hline CETP & 493 & 476 & 1,656 & & 16 \\
\hline
\end{tabular}
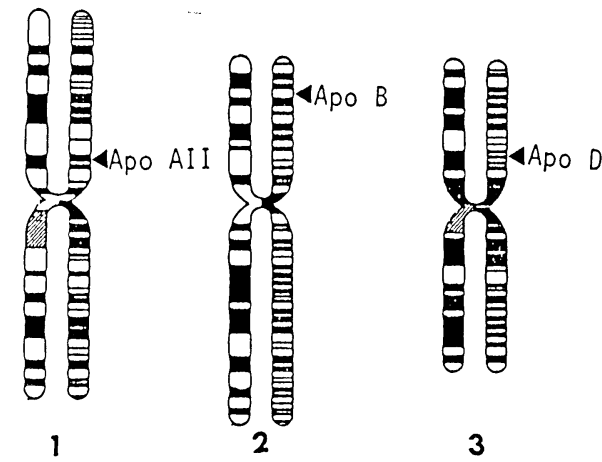

3

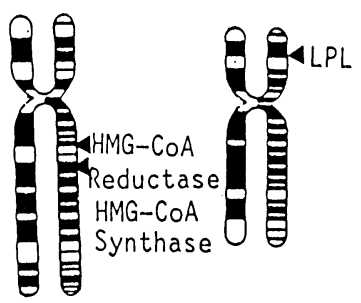

5

8

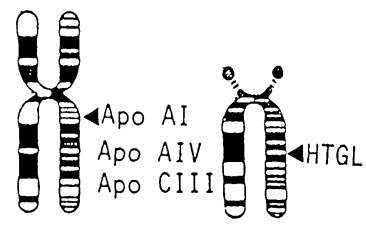

11

15

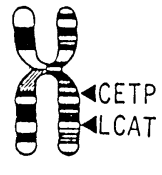

16

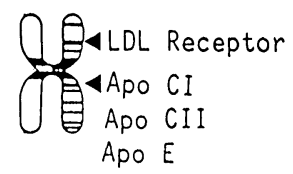

19

Fig. 2 Chromosomal localization of genes for lipid metabolism and transport.

子検討により従来 LDLR 活性からへテロ FH と 考えられていた例がホモ FH と判明した. また $\mathrm{FH}_{\text {TONAMI }} 2$ のホモ FH は妊娠中著明な血清コレ
ステロールの低下を示し，皮膚黄色腫が消失し た ${ }^{4)}$.この $\mathrm{FH}_{\mathrm{TONAMI}} 2$ の LDLR はきわめてエス

トロゲンにより誘導されやすいことが示唆された. 
Table 2 Frequencies of LDLR gene mutation with large deletion

\begin{tabular}{lcc}
\hline \multicolumn{1}{c}{ Mutation } & No. of alleles & Frequency \\
\hline FH Tonami 1 & $5 / 85$ & $5.9 \%$ \\
FH Tonami 2 & $8 / 85$ & $9.4 \%$ \\
FH Kanazawa 1 & $1 / 85$ & $1.2 \%$ \\
\hline \multicolumn{1}{c}{ Total } & $14 / 85$ & $16.5 \%$ \\
\hline
\end{tabular}

アポ蛋白 $\mathrm{E}$ 欠損症5) のアポ蛋白 $\mathrm{E}$ 遺伝子, コレ ステロール転送蛋白 (CETP) 欠損症 ${ }^{6}$ の C CTP 遺 伝子を検討したが，大きな欠損は見いだせず, 1〜 数塩基の異常と推定された.

アポ蛋白 A-I および B の遺伝子多型性 (Restriction fragment length polymorphism, RFLP)と 冠動脈疾患 (CHD) の関連について検討した. Pst I 切断によるアポ蛋白 A-I RFLP は $2.2 \mathrm{~kb}$ と 3.3 $\mathrm{kb}$ バンドが得られ, CHD 患者では $3.3 \mathrm{~kb}$ バン ドの出現頻度は 0.100 , 対照群と有意差がなかっ た7). Msp I 切断によるアポ蛋白 B RFLP は 2.6 $\mathrm{kb}(\mathrm{M} 1)$ と $2.4 \mathrm{~kb}(\mathrm{M} 2)$ のバンドがあり, CHD 群の M1 の出現頻度は 0.096 で対照群 0.045 と差 が認められなかった ${ }^{8)}$.このようにアポ蛋白遺伝 子の RFLP とCHD との閒には直接の因果関係は
認められないが，5'上流の検討などを行えばアポ 蛋白代謝の遺伝的背景が明らかになると思われる.

\section{文献}

1) 暒波康二, 他：LDL 受容体遺伝子の多型性. 動脈 硬化, 15: 919 (1987).

2) Kajinami, K., et al.: New variant of low density lipoprotein receptor gene. FH tonami. Arteriosclerosis, 8: 187 (1988).

3）梶波康二，他：LDL レセプター遺伝子分析により 診断されたホモ接合体性 FH一- FH TONAMI 2. 動 脈硬化，16: 231 (1988).

4) Mabuchi, H., et al.: Normalization of low-density lipoprotein levels and disappearance of xanthomas during pregnancy in a woman with heterozygous familial hypercholesterolemia. Metabolism, 34: 309 (1985).

5) Mabuchi, H., et al.: A young type III hyperlipoproteinemic patient associated with apolipoprotein $\mathbf{E}$ deficiency. Metabolism, 38: 115 (1989).

6) Koizumi, J., et al.: Deficiency of serum cholesterylester transfer activity in patients with familial hyperalphalipoproteinemia. Atherosclerosis, 58: 175 (1985).

7) 伊藤英章, 他：冠動脈硬化症におけるアポ A-I 遺伝 子多型性. 動脈硬化, 15: 1521 (1987).

8) 伊藤英章, 他: 冠動脈硬化症におけるアポ蛋白 B 遺 伝子多型性. 動脈硬化, 16: 260 (1988). 